\title{
Structured Multi-Stakeholder Workshops to Advance a Global Transformative Roadmap for Pharmaceutical Workforce
}

Andreia Bruno ${ }^{1}$, Lina Bader ${ }^{2}$, Ian Bates ${ }^{3}$, Tina Brock ${ }^{1}$, Kirsten Galbraith ${ }^{1}$, Claire Anderson ${ }^{4}$, Ian Larson ${ }^{1}$, Ema Paulino ${ }^{2}$, Michael Rouse ${ }^{5}$, Toyin Tofade ${ }^{6}$, Jill Boone ${ }^{7}$, Joana Carrasqueira ${ }^{8}$, Susan James ${ }^{9}$, Whitley $\mathrm{Yi}^{10}$

${ }^{1}$ Faculty of Pharmacy and Pharmaceutical Sciences, Monash University, Melbourne, Australia

${ }^{2}$ International Pharmaceutical Federation, The Hague, Netherlands

${ }^{3}$ FIP Collaborating Centre, UCL School of Pharmacy, London, United Kingdom

${ }^{4} S$ chool of Pharmacy, University of Nottingham, Nottingham, United Kingdom

${ }^{5}$ Accreditation Council for Pharmacy Education, Chicago, United States of America

${ }^{6}$ Howard University College of Pharmacy, Washington DC, United States of America

${ }^{7}$ University of Cincinnati James L. Winkle College of Pharmacy, Ohio, United States of America

${ }^{8}$ Silicon Valley Innovation Center, San Francisco, United States of America

${ }^{9}$ Ontario College of Pharmacists, Toronto, Canada

${ }^{10}$ University of Colorado Skaggs School of Pharmacy and Pharmaceutical Sciences, Aurora, Colorado, United States of America

\section{ABSTRACT}

In November 2016, the International Pharmaceutical Federation (FIP) endeavored to create an environment to foster a shared vision to lead a transformative pharmaceutical workforce roadmap. Three milestone documents were developed and presented at the Global Conference on Pharmacy and Pharmaceutical Education. Workshops with the key themes and connecting Pharmaceutical Workforce Development Goals (PWDG) were conducted and analyzed. This Note serves to summarize the key aspects of these workshops, reporting on the innovative approaches used to generate guidance for stakeholders regarding implementation.

Innovation: Seven workshops with a uniform structure were developed. These were designed to improve communication, harmonise outcome-generation, and allow for aggregate analysis. A team of seven conducted each workshop, each team consisted of: a Chair, a facilitator, one rapporteur, and four speakers purposively selected from FIP member organisations and other key stakeholders with expertise for sharing a variety of perspectives. Guidelines and templates were developed for all roles and each team was briefed in advance.

Key findings: Approximately 200 personnel participated in the seven workshops, with around 20 country representatives per workshop, covering all six World Health Organisation regions. Three key aspects of workforce transformation, using the PWDGs, were explored in each workshop: drivers for implementation; challenges to implementation; and ways of encouraging implementation. Drivers for implementation mentioned were enhancing collaboration and engagement. Challenges to implementation were identified as variance in terminology. Several ways of encouraging implementation were acknowledged, such as communication strategies, advocating for workforce development and sharing best practices to foster partnerships.

Next steps: The unique format of the workshops, the innovative approach to include stakeholders across an array of settings and the parallel structure in all the seven workshops, aided in creating reliable findings. The achievability of the PWDGs depends on several factors. Engagement with stakeholders and engagement from and between professional associations are important factors to achieving workforce development goals.

Key Words: pharmacy education, pharmaceutical education, transformative education, roadmap, pharmaceutical workforce development goals.

\section{Description}

Creating the pharmaceutical workforce required to adequately address the world's medicines-related needs is an important and complex process. Achieving this requires creating a shared vision, setting agreed objectives, using culturally appropriate strategies for local action, and designing mechanisms for global aggregation of outcomes. These processes cannot be initiated without a critical mass of key decision-makers working together

Corresponding author: Andreia Bruno, Lecturer and Project Manager, Faculty of Pharmacy and Pharmaceutical Sciences, Monash University, Melbourne, Australia

Email: andreia.bruno@monash.edu in an environment of mutual trust to generate guidance. In November 2016, the International Pharmaceutical Federation (FIP) endeavored to create such an environment and use it to premier a transformative pharmaceutical workforce roadmap.

In 2016, a workforce roadmap, including three milestone documents $^{1-3}$ (Global vision for Education and Workforce, Pharmaceutical Workforce Development Goals (PWDGs), Statements on Pharmacy and Pharmaceutical Sciences Education), was developed through a multi-stage consultation with educators, practitioners, policy-makers, and scientists worldwide. The concepts and all the documents were broadly discussed in pharmacy and pharmaceutical sciences 
communities before being endorsed by 153 delegates representing professional bodies and regulatory authorities from 46 countries at the Global Conference on Pharmacy and Pharmaceutical Sciences Education held in Nanjing, China. The creation and endorsement of the workforce roadmap is described in detail in the report entitled, "Transforming pharmacy and pharmaceutical sciences education in the context of workforce development ${ }^{\prime \prime}$.

The $\underline{\text { PWDGs }}^{2}$ can act as a mechanism to prepare a pharmaceutical workforce that is able to better meet pharmaceutical healthcare needs and the development of medicines expertise and science. An adapted framework method analysis ${ }^{5}$ was used to develop the final 13 PWDGs. Extensive external and internal consultation processes included: a review of health workforce literature ${ }^{6,7}$ and FIP Education outputs since 2008 ${ }^{8}$; internal FIP consultation with leadership of Member Organisations, Executive Committee, Bureau, Boards and FIP Education; and a public and organisational consultation. Along with the relevant literature, the PWDGs formed the basis of workshops undertaken at the Global Conference. There are 13 PWDGs, gathered into three clusters: 1) Academy focuses goals for schools, universities and education providers; 2) Professional Development focuses on goals for the pharmaceutical workforce; 3) Systems focuses on goals for policy development, governmental strategy and planning, and monitoring systems. For each, a summative set of drivers, imperatives and indicators is provided to guide pharmaceutical stakeholders in their use to assess the current status of their own workforce development and assist in the development of strategies at a national level.

At the Global Conference and following scene-setting plenary sessions, official conference delegates and other participants representing various aspects of pharmacy and pharmaceutical sciences engaged in novel workshops designed to: a) highlight local work related to the transformation of the pharmaceutical workforce, b) generate ideas for local and global actions in support of the pharmaceutical workforce development goals (PWDGs), and c) propose methods for communication about the PWDGs and progress toward achieving them. Overall, seven multinational workshops were held (see Table 1) centred on key themes gathered previously from the health workforce literature and extended to include the relevant PWDGs. The participants were asked to choose two workshops to attend, resulting in a convenience sampling approach. Participants discussed issues on their roundtables first, then shared their results with the overall group. This Note serves to summarize key aspects of these workshops (that served as basis to understand the feasibility of how the PWDGs could be implemented in different countries), report on the innovative approaches used and major outcomes realized, in order to generate guidance for stakeholders regarding PWDGs implementation.

\section{Innovation}

\section{Workshop selection}

Around 600 registrants attended the Global Conference from 46 countries (including 400 Chinese registrants from the hosting country, who participated in a parallel national Chinese programme). An estimated 200 delegates participated in the seven workshops, with a representation of approximately 20 countries per workshop covering all six World Health Organisation regions (data retrieved from the registration for the conference and workshop attendance lists).

All conference participants were asked to select two workshops in which to participate. Table 1 provides an overview of the workshop topics and questions discussed. Although participants could make this choice based upon their interest, the size of the sessions served to promote diversity of geography, interest, and experience. Workshops included participants from 40 to 60 countries in total, with smaller roundtable groups of between 6 to 8 . Workshop facilitation staff further promoted this diversity by monitoring seating arrangements.

\section{Workshop structure}

A team of seven conducted each workshop. Each team consisted of a Chair from the Conference Steering Committee, a facilitator from the FIP Education Development Team, one rapporteur from the FIP Education Development Team, and four speakers purposively selected from FIP member organisations and other key stakeholders with expertise for sharing a variety of perspectives. Guidelines and templates were developed for all roles and each team was briefed in advance about their responsibilities.

A uniform structure was used for all seven multinational workshops. The structure was designed to improve communication, harmonise outcome-generation, and allow for aggregate analysis. At the start of each workshop, the chair provided an overview of the topic and the relevant PWDGs to contextualise the "how/when/what" of workforce development. The four speakers presented sequentially the "where and why" perspectives, focusing on a principal challenge for their country or organisation, their priority for action, and further insights. Following this, the facilitator introduced an activity designed to stimulate "what's next" dialogue on the topics and case presentations. Rapporteurs created summative reports of these proceedings using proforma templates (see Figure 1).

\section{Workshop outcomes}

At the end of each workshop, the Chair, facilitator and rapporteur collaborated to produce summary slides which were collated and presented at the closing session of the Conference. Presentations of the workshop planning outputs focused on continuing stakeholder engagement, communication of the conference outcomes, action-planning, and monitoring and evaluation of PWDG progress. 
Following the conclusion of the Conference, the Chairs and/or facilitators completed a one-page outcomes template: setting the scene, summarising the workshop, and describing main calls for action. The rapporteur reports, summary slides, and outcomes template were triangulated to provide a comprehensive basis for the analysis of the workshop outcomes. The data was organised by AB and LB using NVivo ${ }^{\circledR}$ software (QSR International; Melbourne, Australia) to detect common themes and patterns. Content analysis was conducted to ensure the common themes were aggregated in response to the three main questions used in all seven workshops. Drivers for implementation, challenges to implementation and dissemination strategies were described. The emerging themes within those topics were categorised and are illustrated in the key findings.

\section{Key Findings}

\section{Drivers for implementation}

Enhanced interprofessional, multi-professional and multistakeholder collaboration was described as an important driver for change (Workshop (WS) 3). Identifying ways to promote better collaboration with stakeholders, overcome organisational and bureaucratic barriers, and building collaborative channels were all discussed by the participants. Promoting interprofessional education (PWDG8) was seen as contributing to enhancing academic capacity (PWDG1) (WS 1).

It was considered that regulatory bodies and the academy will need to collaborate to ensure the profession is aligned with current and changing societal, patient and community needs. Engagement between the academy, government agencies and practicing professionals is critical to ensure that curricular changes align with advances in practice and focus on patient outcomes (PWDG 6 and 9) (WS 5).

The impact of automation and technology on practice, science and education was identified as a potential driver for implementation. It was reported (WS 2, WS 7) that automation can help influence achievability of academic capacity by improving education (e.g. simulation, e-learning).

Foundation training (early career experiential training) was considered crucial to underpin advancement and there was an identified need for policy and education structural changes via a top-down approach. There is also a need for a shared understanding of what advanced and specialist expert development is and for stakeholder recognition about its value (PWDG 2 and 4) (WS 6).

The need for post-registration (or post-licensure) education and training systems to be modified to assure the clinical competence of pharmacists (PWDG 5 and 11) was highlighted. In order to provide patient-focused services within a country, pharmacists must be both adequate in number and competent in a variety of individual and team-based skills. Therefore, in practice, support systems are needed to allow pharmacists to provide clinical services (WS 7).

\section{Challenges to implementation}

The continued lack of collaboration between educational providers and pharmacy stakeholders was reported to be a challenge (PWDG 3); investing in establishing multi-stakeholder networks can help overcome this challenge. Similarly, limited interprofessional collaboration can be a barrier to understanding roles and responsibilities and hence pose as a barrier for implementing PWDG 8 (WS 2, 3).

Variance in terminology and definitions was a recurring theme across all workshops (WS 1, 3, 4, 5, 6) and was identified as being both a driver (if a common terminology could be agreed) and a barrier to implementation (when different meanings can be found globally for the same concept). Defining the workforce development Goals and understanding their meaning and scope are seen as crucial elements to measuring and monitoring progress. The ability to reach consensus on terminology and how terms are defined is seen as a major challenge to global action planning.

WS 4 participants discussed at length their different understandings of PWDG 7 - Service provision and workforce education and training description (for example 'foundation training' was thought by some to be linked to initial education rather than workforce education and training, and by others to be - more aptly - early career training) and stressed the need to clarify the goals given the wide range of the particular workforce needs in each country (PWDG 13). Lack of consensus on terminology was identified as a barrier to achievability as some terminology has different contextual meanings in different countries and monitoring progress can therefore become more difficult; a 'terminology and definitions framework' was suggested as a means to understanding different perceptions (WS 6).

Limitations in resources and technical capacity can hinder the integration of technology and education (WS 1). Financial resources in the form of financial incentives and re-imbursement models may be required to support the development of some goals such as PWDG 8 and PWDG 6. Participants also noted that incentives to achieve collaborative practice may be needed to secure government support to create the expectation practice and payment models needed to truly support delivery of patientcentred care from a collaborative health care team (WS 3). Financial resources are particularly important for driving advanced practice and specialisation (PWDG 4) as remuneration and financial incentives drive the provision of advanced services; professional recognition (financial or otherwise) can also demonstrate tangible benefits for practitioners, thereby encouraging pharmacy advancement and/or specialisation (WS $6)$. 
Ways of disseminating implementation strategy

Top down and bottom up public and organisational communication strategies are key to promoting and disseminating the PWDGs; one example of a top down approach is engaging with health ministries to support the dissemination of the message to local councils and boards (WS 6). Professional leadership associations should also develop communication strategies to disseminate the goals, and support should be provided to develop communication strategies that can support liaison with local regulatory bodies or governments (WS 5). Having a "point person" in each country to communicate national goals to ensure consistent communication was also suggested (WS 2).

Research output and scientific publications are also highlighted as an important dissemination strategy. This includes public communication strategies and developing guidelines for sharing and creating global centres of excellence (WS 4).

Pharmacy leaders' ability to advocate for the workforce and demonstrate to educational, healthcare, and financial policymakers the value of investing in the pharmaceutical workforce is important. This investment is critical for the future of safe and effective medicines development, access and use (WS 7). Alternatively, investing in leadership development programmes targeted at key lead pharmacists in government positions could in turn steer the profession nationally and internationally (WS 5).

Identifying and sharing existing best practices were reported to support goal achievability through needs-based adaptability, learning from real-life cases and examples, and widen contribution and engagement (WS 7). Identifying best practice was seen as a particularly important driver to achieving academic capacity (WS 1). Similarly, identifying Continuing Professional Development (CPD) models from around the world can help countries establish their own CPD programmes (WS 5). Sharing negative experiences was identified as being just as important as sharing best practice to raise awareness on common barriers (WS 6).

Participants called on FIP to work with member organisations to identify all national or regional organizations dedicated specifically to academic pharmacy, quality assurance and CPD providers; local work can be seeded and aggregated and adapted globally; fostering partnerships with global health agencies like the World Health Organisation (WHO) is seen as a driver to goal achievability (WS 2, 3, 4).

\section{Next steps}

The unique format of the workshops, the innovative approach to include stakeholders across an array of settings and the parallel structure in all the seven workshops, aided in creating reliable findings. Several important lessons were learned which are helpful in considering replication of this activity in 5 to 10 years. First, it is critical to have a shared framework, a structured workshop guide and clear roles and responsibilities at the outset. Next having diversity in the country perspectives ensured that issues were considered through different geographical and cultural lenses. Finally, a team approach including both individuals who focus on strategy and individuals who focus on implementation led to the success.

By exploring and discussing the main barriers to workforce transformation, the multi-national workshop sessions were intended as a facilitative tool - due to the innovative way they have been developed and conducted - to identify best practices for promoting change. The workshop delegates and participants represented a range of countries and territories, organizations and scopes of expertise. Participant feedback and workshop outcomes will be used to feed directly into the global transformation agenda led by FIP, under the aegis of FIP Education (FIPEd).

The workshop outcomes are critical for future successful progress towards the Nanjing outcomes, especially the PWDGs. Common themes were identified across the achievability of the goals, assessment and metrics, financial incentives and the role of FIP in promoting uptake and implementation. The achievability of the PWDGs depends on several factors, including consideration of local needs and capacities when adopting the goals. Engagement with stakeholders and engagement from and between professional associations are additional important factors to achieving workforce development goals.

The calls for action have been widely shared along with the other milestone documents of the workforce roadmap. Examples are beginning to emerge regarding the use of the PWDG international conferences have started to request their participants to map the work submitted to the PWDGs (for example the Life Long Learning in Pharmacy conference) and local stakeholders have created collaborations based on the PWDGs. Further work still needs to be conducted to prioritize all the calls for action and plan to transform education, as it has highlighted "now it's time for action" (Table 1).

\section{Contributions by authors}

$A B$ : concept, method design, data collection, data analysis, first draft production, revision of drafts/final versions and final approval of the manuscript.

IB: concept, method design, revision drafts/final version and final approval of the manuscript.

LB: data analysis, revision drafts and final approval of the manuscript.

TB, KG: data submission, revision drafts/final version and final approval of the manuscript.

CA, EP, MR, IL, TT: data submission, revision of final version and final approval of the manuscript.

JB, JC, SJ, WY: data submission and final approval of the manuscript. 
Acknowledgements: We would like to thank the staff and officers of the International Pharmaceutical Federation (FIP), the FIP Executive Committee, the Planning Committee and the participants of Global Conference on Pharmacy and Pharmaceutical Sciences Education for their collaboration.

\section{Funding/Support: None}

\section{Conflicts of Interest: None}

\section{References}

1. International Pharmaceutical Federation (FIP). Global Vision for Education and Workforce. The Hague: FIP, 2016. Available from: http://fip.org/educationreports

2. International Pharmaceutical Federation (FIP). Pharmaceutical Workforce Development Goals. The Hague: FIP, 2016. Available from: http://fip.org/educationreports

3. International Pharmaceutical Federation (FIP).

Statements on Pharmacy and Pharmaceutical Sciences Education. The Hague: FIP, 2017. Available from: http://fip.org/educationreports

4. International Pharmaceutical Federation (FIP). Transforming Pharmacy and Pharmaceutical Sciences Education in the Context of Workforce Development. The Hague: FIP; 2017. Available from: http://fip.org/publications

5. Gale NK, Heath G, Cameron E, Rashid S, Redwood S. Using the framework method for the analysis of qualitative data in multi-disciplinary health research. BMC Medical Research Methodology. 2013;13:117.

6. World Health Organization (WHO). Global strategy on human resources for health: Workforce 2030. Geneva: WHO, 2016. Available from: http://www.who.int/hrh/resources/pub globstrathrh2030/en/

7. United Nations (UN). Transforming our world: The 2030 agenda for sustainable development. New York: UN Publishing, 2015. Available from: https://sustainabledevelopment.un.org/

8. International Pharmaceutical Federation (FIP). Transforming our workforce | Workforce development and education: Systems, tools and navigation. The Hague: FIP; 2016. Available from: http://fip.org/educationreports 
Figure 1: Summary of the Pharmaceutical Workforce Development Goals (PWDGs) workshop process and structure

Process

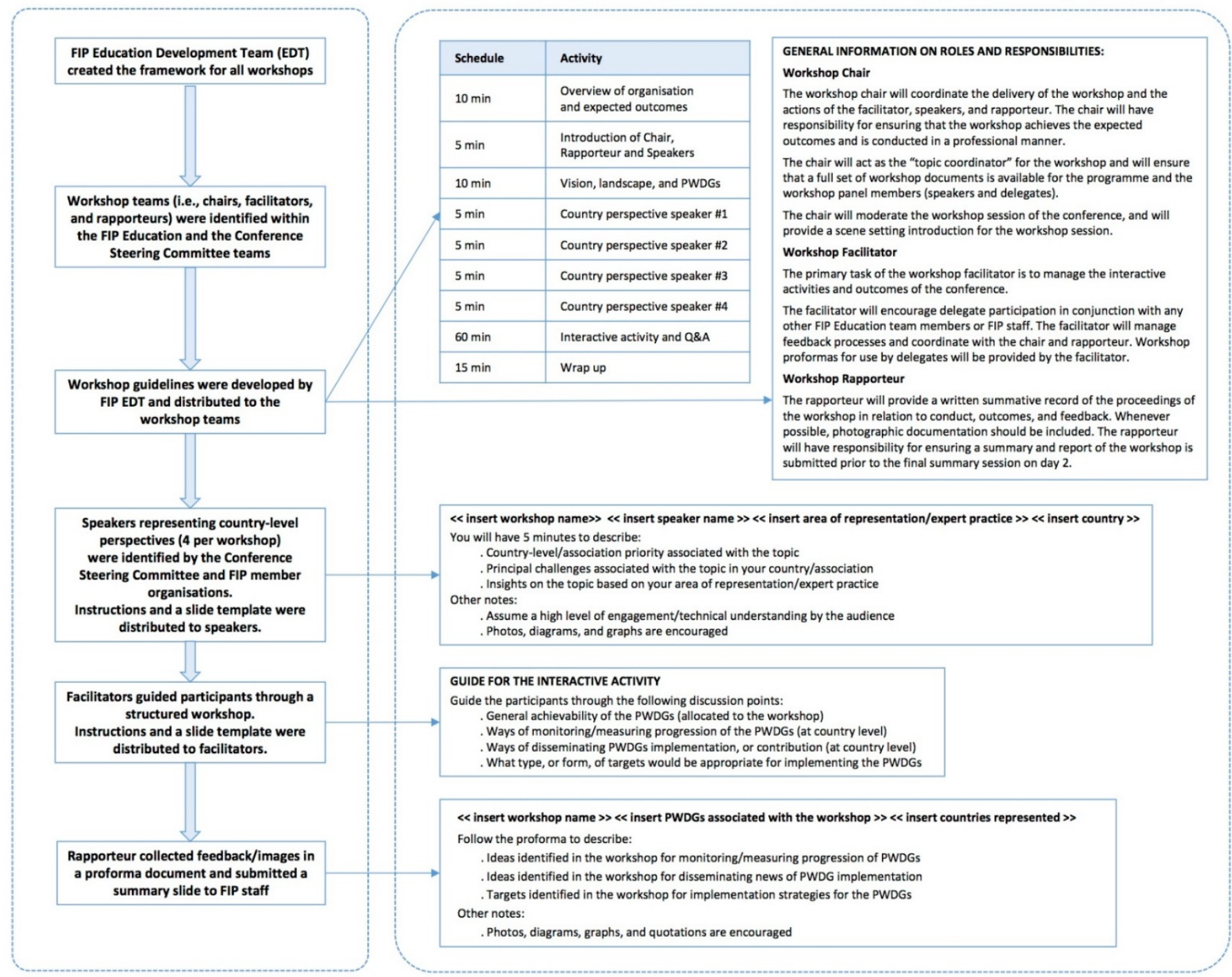


Table 1: Summary of workshop outcomes and calls for action

\begin{tabular}{|c|c|c|c|c|}
\hline $\begin{array}{c}\text { Workshop } \\
\text { title }\end{array}$ & $\begin{array}{c}\text { Related } \\
\text { PWDG(s) }\end{array}$ & $\begin{array}{l}\text { Questions } \\
\text { addressed }\end{array}$ & Summary of key outcomes & Calls for action \\
\hline $\begin{array}{l}\text { Workshop 1: } \\
\text { Initial and } \\
\text { early } \\
\text { education }\end{array}$ & $\begin{array}{c}1 \mid \\
\begin{array}{c}\text { ACADEMIC } \\
\text { ACAPACITY }\end{array}\end{array}$ & $\begin{array}{l}\text { How to align } \\
\text { initial education } \\
\text { with country } \\
\text { needs? It focused } \\
\text { on the first } 1,000 \\
\text { days of practice, } \\
\text { addressing } \\
\text { suitable training } \\
\text { and mentorship } \\
\text { for young } \\
\text { pharmacist and } \\
\text { pharmacy } \\
\text { students. }\end{array}$ & $\begin{array}{l}\text { The definition scope of PWDG } 1 \text { Academic Capacity is } \\
\text { wide and can include a number of concepts such as: } \\
\text { having the right mix of academic expertise; quantity, } \\
\text { quality, infrastructure; optimised learning environment; } \\
\text { and producing pharmacists who can meet country needs } \\
\text { and adapt to future ones. A number of drivers for } \\
\text { implementing the first PWDG were identified, and these } \\
\text { include: automation (e.g., e-learning and simulation); } \\
\text { applying best practices; and creating collaborative } \\
\text { education and training environments. In addition, targets } \\
\text { for implementation can be found in: developing } \\
\text { graduate employability skills; reviewing evaluation } \\
\text { methods; and adopting an outcomes-based learning } \\
\text { system. }\end{array}$ & $\begin{array}{l}\text { While previous work regarding } \\
\text { counting and describing } \\
\text { pharmacy-related academics } \\
\text { has been initiated (e.g. FIP } \\
\text { Global Pharmacy Workforce } \\
\text { reports), the outputs of this } \\
\text { work have not been completed } \\
\text { nor have they been used } \\
\text { widely to drive policy. } \\
\text { Diagnostic models and } \\
\text { benchmarking tools are needed } \\
\text { to enable these numbers and } \\
\text { competencies to motivate } \\
\text { global action as well as to be } \\
\text { useful in needs-based } \\
\text { educational models. } \\
\text { PWDG1 provides an } \\
\text { opportunity to develop the } \\
\text { passive and active surveillance } \\
\text { systems required to produce } \\
\text { the pharmacy-related } \\
\text { workforce necessary for safe } \\
\text { and effective medicines } \\
\text { discovery, manufacture, } \\
\text { distribution, and use worldwide. }\end{array}$ \\
\hline $\begin{array}{l}\text { Workshop 2: } \\
\text { Quality } \\
\text { assurance } \\
\text { and } \\
\text { accreditation }\end{array}$ & 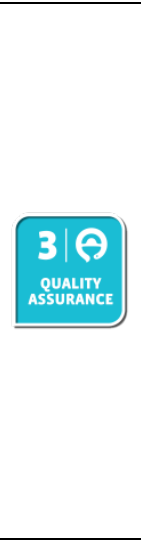 & $\begin{array}{l}\text { How to design, } \\
\text { implement and } \\
\text { assess the quality } \\
\text { of contemporary } \\
\text { educational } \\
\text { programmes? }\end{array}$ & $\begin{array}{l}\text { The challenges in achieving PWDG } 3 \text { can lie in: diversity } \\
\text { within and between countries; resources (e.g., human } \\
\text { resources and funding); stakeholder engagement; } \\
\text { resistance to change; and governmental control and } \\
\text { regulatory constraints. Identifying solutions and } \\
\text { addressing these challenges can be accomplished } \\
\text { through: communicating and collaborating with } \\
\text { stakeholders; developing strategies to incentivise } \\
\text { stakeholders and government bodies; encouraging more } \\
\text { association-driven strategies; seeking FIP assistance and } \\
\text { support; and using tools already developed. Identifying } \\
\text { gaps, conducting needs analyses, setting implementation } \\
\text { targets, and capitalising on existing capacities and } \\
\text { resources can all facilitate achievement of the goal. }\end{array}$ & $\begin{array}{l}\text { There is a need to focus on } \\
\text { demonstrated achievement of } \\
\text { competencies (for pharmacists } \\
\text { and pharmaceutical scientists); } \\
\text { use a systems approach; get } \\
\text { high level WHO support and FIP } \\
\text { engagement; engage people } \\
\text { with the right experience and } \\
\text { expertise to get the job done; } \\
\text { and build on existing strengths. } \\
\text { One participant noted that we } \\
\text { have had many reports but } \\
\text { "now it's time for action." }\end{array}$ \\
\hline $\begin{array}{l}\text { Workshop 3: } \\
\text { Educating } \\
\text { for } \\
\text { collaborative } \\
\text { working }\end{array}$ & 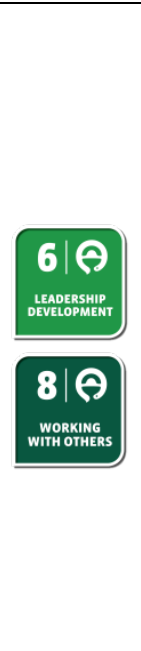 & $\begin{array}{l}\text { How can } \\
\text { interprofessional, } \\
\text { intraprofessional } \\
\text { education, and } \\
\text { models of } \\
\text { collaboration } \\
\text { between higher } \\
\text { education } \\
\text { institutions, } \\
\text { sectors, science } \\
\text { and practice be } \\
\text { achieved? }\end{array}$ & $\begin{array}{l}\text { Achieving leadership, PWDG 6, depends on students } \\
\text { being provided with early leadership development } \\
\text { opportunities and having leadership as part of } \\
\text { accreditation standards. Applying leadership skills is } \\
\text { imperative in developing relationships with other } \\
\text { professionals to enhance collaboration. Achieving PWDG } \\
8 \text { depends on nurturing collaborative skills in pharmacy } \\
\text { students from the first semester onward, as well as } \\
\text { developing more collaborative experiential training } \\
\text { programmes. Transparency, trust and confidence are } \\
\text { integral to successful collaborative practice. } \\
\text { Collaborative practice drivers such as engagement from } \\
\text { professional associations, credentialing incentives and } \\
\text { remuneration models can facilitate achieving PWDG } 8 . \\
\text { Examples of ways to disseminating implementation } \\
\text { include establishing guidelines, scientific publications } \\
\text { and centres of excellence. }\end{array}$ & $\begin{array}{l}\text { - Developing interprofessional } \\
\text { education throughout the world } \\
\text { is a very important initiative for } \\
\text { preparing pharmacists for team } \\
\text { models of care. } \\
\text { Academia, professional } \\
\text { associations and regulators all } \\
\text { play a role in advancing IPE and } \\
\text { must work together to advance } \\
\text { this effort. }\end{array}$ \\
\hline
\end{tabular}




\begin{tabular}{|c|c|c|c|c|}
\hline $\begin{array}{l}\text { Workshop 4: } \\
\text { Practice and } \\
\text { science }\end{array}$ & 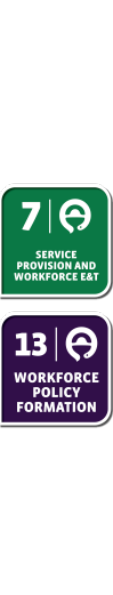 & $\begin{array}{l}\text { How does } \\
\text { education } \\
\text { prepare sciences } \\
\text { to translate into } \\
\text { practice and } \\
\text { practice to } \\
\text { inform science? }\end{array}$ & $\begin{array}{l}\text { Participants discussed goals terminology, demonstrating } \\
\text { the importance of reaching consensus on definitions. } \\
\text { They also shared ways of integrating science and practice } \\
\text { through education. One example was through } \\
\text { redesigning initial education such that pharmacy } \\
\text { students are introduced to practice from day } 1 \text {. In } \\
\text { addition to undergraduate education, targeting } \\
\text { postgraduate studies can be a means to science/practice } \\
\text { integration (e.g., clinical practice-based research and } \\
\text { data collection). Recalibrating the curriculum to } \\
\text { accommodate new emerging therapies and advanced } \\
\text { services was also identified. Introducing innovative } \\
\text { modules that allow students to design new } \\
\text { pharmaceutical services would encourage them to think } \\
\text { about the link between science and practice. }\end{array}$ & $\begin{array}{l}\text { - In summary, participants were } \\
\text { confused by the workshop title } \\
\text { and thought that FIP needed to } \\
\text { improve the clarity of PWDG 7's } \\
\text { description (e.g. 'foundation' } \\
\text { was thought to be linked to } \\
\text { initial education rather than } \\
\text { workforce education and } \\
\text { training). } \\
\text { Some participants thought it } \\
\text { would be particularly useful for } \\
\text { FIP to undertake an } \\
\text { international survey of CPD } \\
\text { requirements, resources and } \\
\text { quality. }\end{array}$ \\
\hline $\begin{array}{l}\text { Workshop 5: } \\
\text { Educating } \\
\text { for future } \\
\text { goals }\end{array}$ & 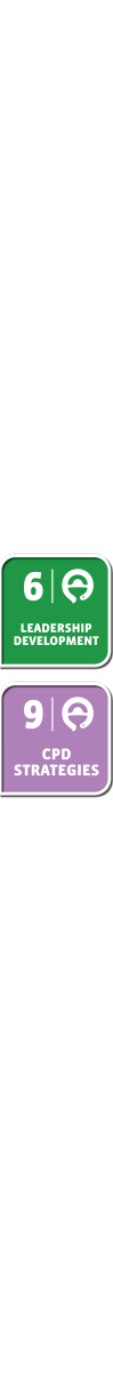 & $\begin{array}{l}\text { How can we } \\
\text { strategize future } \\
\text { roles for } \\
\text { pharmacists and } \\
\text { pharmaceutical } \\
\text { scientists, } \\
\text { including the } \\
\text { scope, } \\
\text { technological, } \\
\text { clinical and } \\
\text { scientific } \\
\text { aspects? }\end{array}$ & $\begin{array}{l}\text { It is important to understand the motivating factors that } \\
\text { influence pharmacists' CPD habits in order to address the } \\
\text { challenges facing goal achievability. It is also important } \\
\text { for FIP to communicate strategies to member } \\
\text { organisations to help them engage with stakeholders, } \\
\text { such as the government, in order to facilitate meeting } \\
\text { the PWDGs. Updated documents and guidance } \\
\text { documents are a critical first step towards achieving the } \\
\text { goals. } \\
\text { Outcomes regarding PWDG } 6 \text { on leadership development } \\
\text { resonate with other workshop outcomes for the same } \\
\text { goal. Empowering students with leadership-fostering } \\
\text { activities has been identified as a key driver. Targeting } \\
\text { mentoring programmes and creating centres of } \\
\text { excellence can benefit both PWDGs } 6 \text { and } 9 \text {. } \\
\text { Disseminating the implementation of PWDG } 6 \text { depends } \\
\text { on developing specific processes describing how } \\
\text { pharmacists can be engaged to take up leadership } \\
\text { programmes. }\end{array}$ & $\begin{array}{l}\text { - In order to achieve significant } \\
\text { strides in these CPD and } \\
\text { leadership goals, we must step } \\
\text { out of our comfort zones and } \\
\text { include appropriate social and } \\
\text { psychological skills in the } \\
\text { professional learning paradigm } \\
\text { for our students in our } \\
\text { universities. } \\
\text { Student organizations will need } \\
\text { financial support to encourage } \\
\text { budding student leaders in the } \\
\text { profession. } \\
\text { Mentors should encourage } \\
\text { talented pharmacists to seek } \\
\text { leadership positions of } \\
\text { influence in our communities. } \\
\text { The organization will need to } \\
\text { define core skills, behaviours } \\
\text { and attitudes consistent with } \\
\text { strong leadership at the } \\
\text { student, administrator and } \\
\text { professional practice level. } \\
\text { FIP should play a more active } \\
\text { role in supporting national } \\
\text { development of CPD } \\
\text { Programmes and efforts to } \\
\text { initiate such particularly in } \\
\text { developing countries. } \\
\text { Leadership development } \\
\text { programmes should be } \\
\text { targeted to key lead } \\
\text { pharmacists in government } \\
\text { positions that could steer the } \\
\text { profession nationally and } \\
\text { worldwide. }\end{array}$ \\
\hline
\end{tabular}




\begin{tabular}{|c|c|c|c|c|}
\hline $\begin{array}{l}\text { Workshop 6: } \\
\text { Educating } \\
\text { for advanced } \\
\text { practice }\end{array}$ & 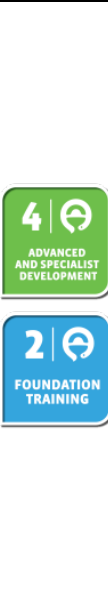 & $\begin{array}{l}\text { How can } \\
\text { specialisation, } \\
\text { professional } \\
\text { development, } \\
\text { professional } \\
\text { recognition and } \\
\text { credentialing, } \\
\text { advance } \\
\text { practice? }\end{array}$ & $\begin{array}{l}\text { There are major variances among different countries, in } \\
\text { terms of terminology recognition, legislation and scope } \\
\text { of practice, infrastructures of practice sites, and existing } \\
\text { support structure (e.g., professional organisations). } \\
\text { Sharing experiences (both positive and negative) and } \\
\text { best practices is important to achieving the goals. There } \\
\text { is a need for top-down policy and educational structural } \\
\text { changes to progress advanced and specialist } \\
\text { development and practice. Expanding the role of FIPEd } \\
\text { beyond congresses and reports to disseminating "how } \\
\text { to" guides that can assist with real policy } \\
\text { implementation is important. Also, developing a global } \\
\text { advanced practice and specialisation framework (in } \\
\text { addition to the FIP competency framework that already } \\
\text { exists) can help countries advance practice in their } \\
\text { jurisdictions. }\end{array}$ & $\begin{array}{l}\text { - Pharmacy needs a workforce } \\
\text { that is flexible, capable, } \\
\text { demonstrable, adaptable, able } \\
\text { to move across sectors and } \\
\text { adapt to changing care models. } \\
\text { To achieve this, pharmacists } \\
\text { should not specialise too early } \\
\text { in their training. } \\
\text { Foundation training should } \\
\text { underpin advancement, and } \\
\text { advanced and specialist } \\
\text { development should follow, } \\
\text { whenever relevant for both } \\
\text { practitioner and patient. }\end{array}$ \\
\hline $\begin{array}{l}\text { Workshop 7: } \\
\text { Clinical } \\
\text { practice }\end{array}$ & 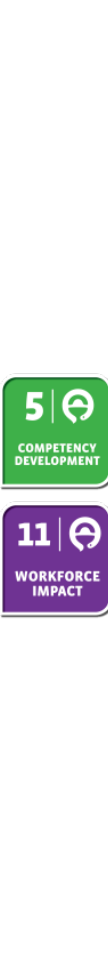 & $\begin{array}{l}\text { How to transform } \\
\text { education of } \\
\text { pharmacists to } \\
\text { better prepare } \\
\text { them for clinical } \\
\text { roles? }\end{array}$ & $\begin{array}{l}\text { There is consensus that clinical practice refers to patient- } \\
\text { focused care in any practice setting and that expanding } \\
\text { the role of pharmacists in clinical practice is both } \\
\text { desirable and achievable. There are a number of drivers } \\
\text { to embracing clinical roles: refining practice scope and } \\
\text { activities to have time for clinical practice; fostering new } \\
\text { ways of working that connect pharmacists to other } \\
\text { members of the healthcare team; establishing } \\
\text { remuneration systems for the outcomes of clinical } \\
\text { services; and assuring competence to deliver excellent } \\
\text { patient care. Additionally, there are regional differences } \\
\text { regarding progress toward clinical services, and countries } \\
\text { developing new services may benefit from learning } \\
\text { lessons from others that have already implemented } \\
\text { clinical practices. }\end{array}$ & $\begin{array}{l}\text { The workshop consensus was } \\
\text { that the role of the pharmacist } \\
\text { should be clinical practice: it is } \\
\text { desirable, achievable, and } \\
\text { applicable in any setting. } \\
\text { The presentations suggested } \\
\text { that there are positive examples } \\
\text { from countries in both high and } \\
\text { low resource settings. } \\
\text { Pharmacy leaders are needed } \\
\text { to facilitate the changes } \\
\text { required to advance clinical } \\
\text { practice. } \\
\text { Standards for educating and } \\
\text { training clinical pharmacists } \\
\text { need to be agreed upon and } \\
\text { disseminated. } \\
\text { Regions developing new clinical } \\
\text { services may benefit from } \\
\text { learning successes and avoiding } \\
\text { hurdles of others who have } \\
\text { implemented clinical practices. } \\
\text { It is imperative for professional } \\
\text { organizations to provide forums } \\
\text { to facilitate this learning. }\end{array}$ \\
\hline
\end{tabular}

